\title{
Prevalence, knowledge and attitudes concerning dietary supplements among inhabitants of Vukovar, Republic of Croatia
}

\author{
Ivana Baralić I1,2, Brižita \\ Đorđević3 ${ }^{3}$ Senka Milinković ${ }^{4}$ \\ Srbija \\ 2University of Bijeljina, Faculty of \\ Srpska \\ of Pharmacy, University of Belgrade, \\ Vojvode Stepe 450, 11000 Belgrade, \\ Srbia \\ ${ }^{4}$ ZUA Zegin Farm - department Šid, \\ 22240 Šid, Serbia \\ Corresponding author: \\ Ivana Baralić \\ Vatroslava Lisinskog 19/17 \\ 11000 Beograd \\ Tel:0011/2764-224 \\ E-mail address: \\ ivanabaralic111@gmail.com
}

'Zvezdara University Medical Center, Dimitrija Tucovića 161, 11000 Beograd, Pharmacy, 76300 Bijeljina, Republika

${ }^{3}$ Department of Bromatology, Faculty

\begin{abstract}
Analysis of dietary supplement (DS) use is very important in view of the extent of their use, and may indicate the need and ways of rationalizing the use of such products. The aim of this research was to evaluate the frequency of use, the type of most frequently used dietary supplements, the reasons for use, the sources of information and recommendations for dietary supplements, the information and attitudes of users about dietary supplements in the city of Vukovar, Republic of Croatia, as well as the relationship of use with age, sex and education. The descriptive epidemiological examination included 173 subjects, who were users/patients of the pharmacy "Tea-pharm" in Vukovar and who voluntarily filled an anonymous survey. In order to collect data, the original questionnaire was used. Out of the total number of respondents, $9.8 \%$ said they regularly use dietary supplements, $37.0 \%$ of the respondents use it occasionally, while most of the subjects do not use dietary supplements at all. Women significantly more often (53.6\%) used dietary supplements in comparison to men (38.2\%). Regular as well as occasional use of dietary supplements is the most common among those with higher education. Most of the users (36) indicated improvement in immunity as reason of use of dietary supplements. Most of the users (73.8\%) buy dietary supplements in pharmacies, then in grocery stores $11.3 \%$, only $10.0 \%$ of the users buy dietary supplements in the supermarket. The majority of respondents received information on dietary supplements from pharmacists and doctors. This study showed lower regular and occasional use of dietary supplements in the examined population, compared to the results shown in previous studies in developed countries. It has been shown that more frequent use of dietary supplements is associated with female sex, higher education level, and older age. Users buy dietary supplements mainly in pharmacies and receive information from pharmacists and doctors. It is therefore very important that pharmacists have adequate education, so they are able to advise patients properly on use of dietary supplements.
\end{abstract}

Key words: dietary supplements, health workers, prevalence of use.

\section{UVOD}

Dijetetski suplementi (DS) su proizvodi koji predstavljaju koncentrovane izvore vitamina, minerala i drugih supstanci sa nutritivnim ili fiziološkim efektom, čija je funkcija da obogate ishranu u cilju održanja zdravlja. Sastojci DS mogu biti vitamini, minerali, zatim aminokiseline, esencijalne masne kiseline, vlakna, organi i ekstrakti biljnih vrsta, mikroorganizmi, jestive gljive, alge, pčelinji proizvodi i druge supstance. $U$ prometu se nalaze u obliku doziranih farmaceutskih oblika, koji se uzimaju u odmerenim pojedinačnim količinama u obliku tableta, kapsula, pastila, praška u kesicama, rastvora u ampulama i drugo [1].

Broj i vrsta DS koji su dostupni na tržištu raste kontinuirano i kod nas i u svetu. Postoji velika zastuplje- nost DS u medijima, uključujući reklame, informativne članke, studije, koje ukazuju na povezanost upotrebe DS i zdravlja. Zainteresovanost za upotrebu DS je visoka i sve je veći broj ljudi koji in koriste. Učestalost upotrebe DS u razvijenim zemljama (Amerika, Danska, Australija) je oko $50 \%$, a najčešće korišćeni DS su multivitaminsko-mineralni preparati, vitamin C, vitamin $\mathrm{E}$, kalcijum, omega- masne kiseline, glukozamin itd. [2-5]. Kulturološki, socio-demografski, ekonomski i drugi faktori mogu uticati na učestalost upotrebe i vrstu DS koje se najviše koriste. Upotreba DS se povezuje sa zdravim načinom života (uzdržavanje od pušenja, niži indeks telesne mase, fizička aktivnost). Sa druge strane i ekonomski faktori, kao što su veći prihodi, viši nivo zdravstvenog osiguranja i viši nivo obrazovanja, su značajni prediktori učestalosti upotrebe DS [6]. 
Pojedinci kupuju dijetetske suplemente iz više razloga: nadoknada deficita u ishrani, unapređenje zdravlja i kondicije, jačanje imuniteta, sprečavanje posledica stresa, zadovoljavanje povećanih potreba tokom trudnoće, u cilju smanjenja telesne mase, tokom odvikavanja od pušenja, poboljšanje sportske sposobnosti, kao dodatak terapiji bolesti [6-9]. Informacije i preporuke za upotrebu DS korisnici dobijaju od lekara, farmaceuta i drugih zdravstvenih radnika. Pored toga, korisnicima dijetetskih suplemenata su dostupne brojne informacije o DS preko interneta, štampe, televizije, radija, prijatelja, porodice. Značajan broj korisnika upotrebljava DS isključivo na osnovu svog stava i mišljenja [1].

Cilj ovog istraživanja je bio da se proceni učestalost upotrebe DS, vrsta najčešće korišćenih DS, razlog upotrebe, izvori informacija i preporuke za upotrebu DS, informisanost i stavovi o DS korisnika u gradu Vukovaru, Republika Hrvatska, kao i njihova povezanost sa godinama, polom i obrazovanjem.

\section{MATERIJAL I METODE}

Studija je dizajnirana kao deskriptivna studija preseka. U istraživanju je učestvovalo 173 ispitanika (97 žena i 76 muškaraca), koji su bili korisnici/pacijenti apoteka „Tea-pharm (Vaše zdravlje)“ u Vukovaru. Podaci o informisanosti, upotrebi i stavovima o DS među ispitanicima prikupljeni su originalnim epidemiološkim upitnikom, koji su korisnici/pacijenti popunjavali prilikom posete apoteci, u periodu januar - mart 2016. godine. Anketa je bila anonimnog karaktera. Ispitanici su samostalno i u pisanoj formi odgovarali na kratka postavljena pitanja.

Upitnik je razvijen nakon detaljnog pregleda literature, koji je prvobitno sproveden od strane glavnog istraživača i izabrani su istraživački radovi koji su ušli u uži izbor za dalju diskusiju istraživačkog tima. Svi stavovi, razmišljanja i brige vezani za ovo istraživanje uzeti su u obzir prilikom dizajniranja upitnika. Prvi nacrt upitnika je formiran nakon što je istraživački tim detaljno pregledao sve odabrane radove [4-6]. Iskusni nezavisni istraživači su pregledali sva pitanja upitnika i postignut je konsenzus u pogledu jasnoće i važnosti svakog pitanja. Zatim su četiri ispitanika koji su ispunjavali kriterijume za uključenje u istraživanju i nisu bili upoznati sa ovom studijom, popunjavali upitnik. Njihovi komentari su bili iskorišćeni za dalje usavršavanje upitnika.

Korišćeni upitnik se sastojao od četiri dela, sa ukupno postavljenih 20 pitanja. Prvi deo upitnika sadržavao je pitanja o demografskim karakteristikama (pol, starost, obrazovanje). Drugi deo činila su pitanja o upotrebi DS: da li se DS koriste redovno ili povremeno; koje dijetetske suplemente ispitanik koristi (upitnikom su bili obuhvaćeni vitaminski i mineralni dodaci - vitamin $A$, vitamini $B$ grupe, vitamini $C, D, E$, kalcijum, magnezijum, željezo, cink, selen, Co Q 10, omega-3 masne kiseline, beta glukan i biljni preparati); koliki broj preparata ispitanik koristi. Svaki učesnik je bio upitan koji je razlog upotrebe dijetetskih suplemenata, da li se pridražava uputstva za upotrebu, da li čita deklaraciju. Treća grupa pitanja su bila pitanja vezana za informisanost i stavove: koji su izvori informacija o dijetetskim suplementima, mesto kupovine, da li su informacije dobijene od farmaceuta dovoljne i potpune, stavovi o povoljnim i neželjenim efektima dijetetskih suplementa na zdravlje, mišljenje o ceni dijetetskih suplemenata. Sva pitanja u upitnika imala su ponuđene odgovore, osim pitanja koje se odnosilo na zanimanje.

Korisnici/pacijenti su podeljeni prema polu (M/Ž), prema starosti (18-28 godina, 28-38 godina, 38-48 godina, 58-68 godina, preko 68 godina) i prema obrazovanju (osnovna škola, srednja škola, viša škola, fakultet).

Rezultati istraživanja su obrađeni standardnim statističkim metodama, a potom sistematizovani i prikazani tabelarno i grafički upotrebom MS Excel i Word programa. Za statističku obradu podataka korišćen je komercijalno dostupan statistički softver SPSS, verzija 10.0.

\section{REZULTATI}

Deskriptivnim epidemiološkim ispitivanjem obuhvaćeno je 173 ispitanika, različitog pola, starosti i nivoa obrazovanja, koji su bili korisnici/pacijenti apoteka „Teapharm (Vaše zdravlje)" u Vukovaru. Među ispitanicima dominirale su pripadnice ženskog pola. Najveći broj ispitanika pripadao je starosnoj grupi od 28-38 godina i imao je srednji nivo obrazovanja. Sociodemografske karakteristike ispitanika prikazane su u Tabeli 1.

Tabela 1. Sociodemografske karakteristike ispitanika.

\begin{tabular}{|l|l|}
\hline Karakteristike & \multicolumn{1}{|l|}{ Ispitanici, n (\%) } \\
\hline Pol & $97(56,0)$ \\
\hline Žene & $76(43,9)$ \\
Muškarci & \\
\hline Starosna grupa & $31(17,9)$ \\
\hline $18-28$ godina & $46(26,5)$ \\
28-38 godina & $32(18,4)$ \\
38-48 godina & $30(17,3)$ \\
48-58 godina & $22(12,7)$ \\
58-68 godina & $12(6,9)$ \\
Više od 68 godina & $13(7,5)$ \\
\hline Obrazovanje & $116(67,0)$ \\
\hline Osnovna škola & $20(11,5)$ \\
Srednja škola & $24(13,2)$ \\
Viša škola &
\end{tabular}

Od ukupnog broja ispitanika, 9,8 \% izjasnilo se da redovno koristi DS, 37,0 \% ispitanika da povremeno koristi, dok najveći broji ispitanika, i to 53,2 \% uopšte ne koristi DS. Žene su znatno češće $(53,6 \%)$ u odnosnu na 
muškarce (38,2 \%), koristile DS. Povremena upotreba DS je značajno češća kod žena $(44,3 \%)$ u odnosu na muškarce $(29,0 \%)$, dok je redovna upotreba DS podjednako zastupljena među ispitanicima ženskog $(9,3$ $\%)$ i muškog $(9,2 \%)$ pola. U suplementaciji je najčešće korišćen samo jedan preparat (56,2\%). Učestalost upotrebe DS se razlikovala među različitim starosnim grupama (Slika 1). Najčešće su DS koristili ispitanici starosti od 38-48 godina $(59,4 \%)$ i ispitanici stariji od 68 godina $(58,3 \%)$.

Slika 1 . Učestalost upotrebe dijetetskih suplemenata po starosnim grupama

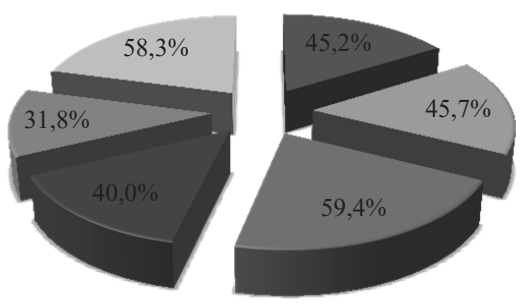

$\square 18-28$ god.
$\square 28-38$ god.
$\square 38-48$ god.
$\square 48-58$ god.
$\square 58-68$ god.
$\square$ više od 68 god.

Ispitanici sa osnovnom školom u većem procentu $(61,5 \%)$ ne koriste DS u odnosu na ispitanike sa srednjom školom (56,0 \%) i ispitanike sa višom školom i fakultetom (45,5\%). Redovna, kao i povremena upotreba DS je najčešća među ispitanicima sa visokim obrazovanjem.

Na slici 2 prikazana je učestalost upotrebe navedenih DS. Najčešće korišćeni preparati bili su magnezijum i vitamin C. Omega-3 masne kiseline, gvožđe, beta glukan, vitamin A i E su najređe korišćeni DS. Selen i CoQ10 niko od anketiranih nije upotrebljavao.

Slika 2. Najčešće upotrebljavani preparati u suplementaciji

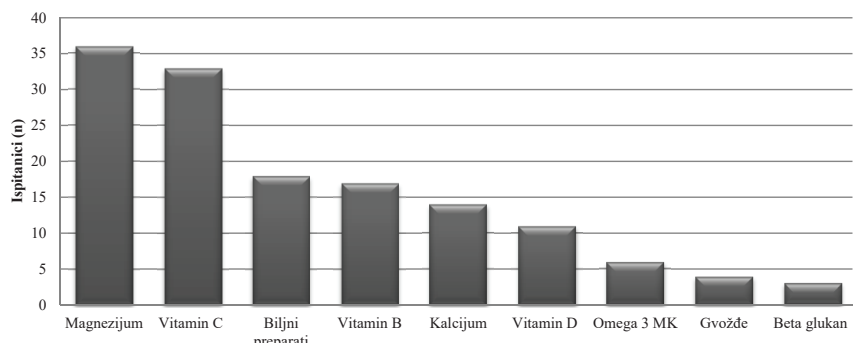

Utvrđeno je da su žene znatno češće koristile magnezijum u odnosu na muškarce. Pored toga, žene su češće koristile kalcijum i vitamin $D$, zatim gvožđe. Upotreba vitamina B kompleksa, vitamina C, biljnih preparata i ostalih suplemenata (multivitamina, proteina) je bila češća među pripadnicima muškog pola. Upotreba omega-3 masnih kiselina je ujednačena i kod žena i kod muškaraca. Beta glukan su koristile samo žene (Tabela 2).

Kao razlog upotrebe, najveći broj ispitanika (36 ispitanika), navelo je unapređenje imuniteta, a 34 is-
Tabela 2. Vrste dijetetskih suplemenata i njihova upotreba po polu.

\begin{tabular}{|l|l|l|l|l|}
\hline \multirow{2}{*}{ Dijetetski suplement } & \multicolumn{2}{l|}{ Žene, $\mathbf{n = 5 2}$} & \multicolumn{2}{l|}{ Muškarci, $\mathbf{n = 2 8}$} \\
\cline { 2 - 5 } & $\mathbf{n}$ & $\mathbf{\%}$ & $\mathbf{n}$ & $\mathbf{\%}$ \\
\hline B kompleks & 10 & 19,2 & 7 & 25,0 \\
\hline Vitamin C & 16 & 30,8 & 15 & 53,6 \\
\hline Vitamin D & 8 & 15,4 & 3 & 10,7 \\
\hline Beta glukan & 3 & 5,8 & 0 & 0,0 \\
\hline Biljni preparati & 10 & 19,2 & 8 & 28,6 \\
\hline Kalcijum & 12 & 23,1 & 2 & 7,1 \\
\hline Magnezijum & 25 & 48,1 & 11 & 39,3 \\
\hline Gvožđe & 3 & 5,8 & 1 & 3,6 \\
\hline $\begin{array}{l}\text { Omega 3 masne } \\
\text { kiseline }\end{array}$ & 4 & 7,7 & 2 & 7,1 \\
\hline $\begin{array}{l}\text { Ostali ( multivitamini, } \\
\text { proteini ) }\end{array}$ & 5 & 9,6 & 4 & 14,3 \\
\hline
\end{tabular}

pitanika je navelo unapređenje zdravlja. Drugi razlozi upotrebe su prevencija bolesti i unapređenja ishrane. Samo 7 anketiranih, DS koristi zbog prisustva osnovnih bolesti (Slika 3).

Slika 3. Razlozi upotrebe dijetetskih suplemenata

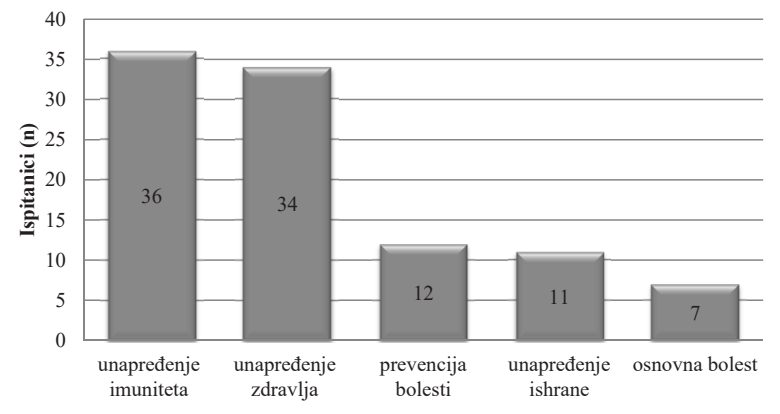

Najveći broj ispitanika (73,8\%) DS kupuje u apotekama, zatim u prodavnicama zdrave hrane $11,3 \%$, u supermarketu samo 10,0\% ispitanika, a zamenarajući deo $(5,0 \%)$ kupuje DS preko interneta (Slika 4).

Slika 4. Mesto kupovine dijetetskih suplemenata

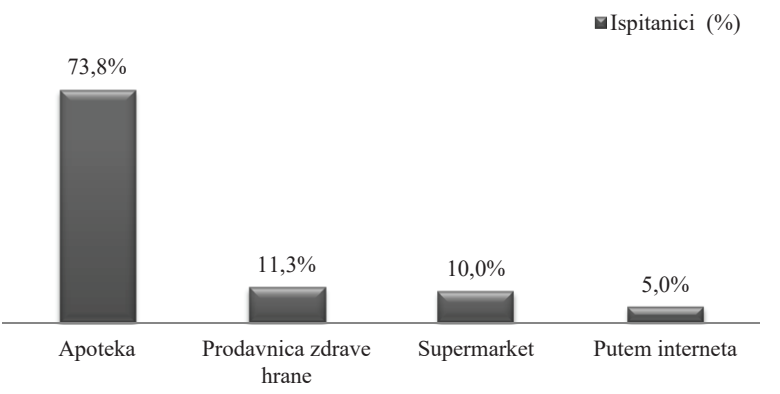

Najveći broj ispitanika je informacije o DS dobio od farmaceuta i lekara $(26,2 \%$ i $22,5 \%$, redom), putem interneta i prijatelja informacije je dobilo 16,3\% korisnika, 
od članova porodice $12,5 \%$, a putem TV-a i štampe manji broj ispitanika (5,0\% i 3,0\%, redom) (Slika 5).

Slika 5. Izvori informacija o dijetetskim suplementima

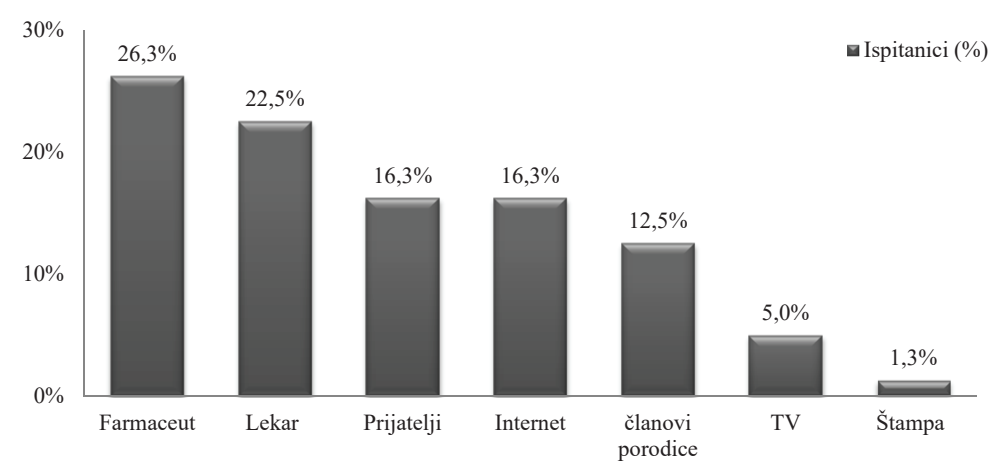

Najveći broj žena $(73,0 \%)$ ima samo jedan izvor informacija, a to su lekar (23,0\%), farmaceut $(23,0 \%)$ i ostali (26,9\%), dok je više izvora navelo $27,0 \%$ žena. Najveći broj ispitanika muškog pola $(60,7 \%)$ je navelo jedan izvor informacije, a to je u najvećem broju bio internet. Ni jedan muškarac nije dobio nikakvu informaciju od lekara, dok je samo 5 ispitanika kao izvor informacija navelo farmaceuta. Najveći broj korisnika DS $(80,0 \%)$ je smatralo da od farmaceuta dobijaju dovoljno informacija o upotrebi DS, dok je $20,0 \%$ to negiralo. Više od polovine ispitanika $(65,0 \%)$ je smatralo da su dovoljno informisani o DS. Žene su više informisane nego muškarci. Prilikom upotrebe, čak 94,0 \% korisnika DS se pridržavao uputstva za upotrebu. Veliki deo ispitanika $(82,5 \%)$ je smatrao je da je važno čitati deklaraciju. Žene su više čitale deklaraciju u odnosu na muškarce $(90,4 \%$ i $67,9 \%$, redom).

Najveći broj ispitanika koji koriste DS $(93,7 \%)$ se izjasnilo da DS imaju povoljne efekte po zdravlje, dok ostali navode da nisu prepoznali korisne efekte tokom upotrebe DS. Najveći broj ispitanika (91,0\%), koji koriste DS, bi preporučio upotrebu DS. Mali broj ispitanika je imalo neželjene efekte (6,3\%), dok je 93,7\% potvrdilo da nije imalo neželjene efekte. Da su DS skupi smatra $80,0 \%$ anketiranih, a ostali da nisu skupi i da je cena pristupačna.

\section{DISKUSIJA}

Saznanja ove studije pokazuju relativno nisku učestalost upotrebe DS među stanovnicima grada Vukovara, Republika Hrvatska. Pokazano je da češća upotreba DS povezana sa ženskim polom, višim nivoom obrazovanja, kao i sa starijom dobi ispitanika. Za razliku od drugih zemalja, naši ispitanici uglavnom DS kupuju apotekama i najviše informacija dobijaju od farmaceuta i lekara.

U ovom istraživanju upotrebu DS navelo je $46,8 \%$ ispitanika. Samo 9,8\% ispitanika redovno koristi DS, dok $37 \%$ DS koristi povremeno, što je značajno manje u odnosu na ispitanike u prethodno objavljenim studijama
$[4,5,10]$. U većem broju studija, preko $50 \%$ ispitanika je koristilo DS. Istraživanje Saveta za odgovornu ishranu koje je obuhvatilo period od 2007-2011 je pokazalo da oko 50\% Amerikanaca "redovno" koristi suplemente. Ako se uzme u obzir i povremena upotreba, skoro 2/3 Američke populacije koristi DS [2]. Istraživanje u Danskoj je pokazalo da $71 \%$ ispitanika starosti od 50 do 64 godine koristi DS u poslednjih 12 meseci [3]. Kao i u drugim studijama $[4,5]$, najveći broj ispitanika je koristio jedan preparat. Niska učestalost upotrebe među ispitanicima obuhvaćenim ovim istraživanjem, može se povezati sa visokom cenom DS, niskim primanjima, visokom stopom nezaposlenosti, i sa velikim iseljavanjem ljudi iz ovog grada. Anketa o nacionalnom pregledu zdravlja i ishrane-2011-2014 (engl. National Health and Nutrition Examination Survey-NHANES) koje je obuhvatila preko 11.000 ispitanika, pokazala je da svi korišćeni indikatori ekonomskog statusa (primanja, zdravstveno osiguranje...) utiču na učestalost upotrebe DS, kao i na vrstu i broj DS koji se koriste [4].

Mnoge prethodno objavljene studije su pokazale da je upotreba DS raširenija kod starijih osoba u odnosu na mlade, i da je u svakoj starosnoj grupi upotreba DS češća među ženama $[3,4,7,11]$. I rezultati našeg istraživanja pokazuju da veći broj žena u odnosu na muškarce koristi DS. Anketa o nacionalnom pregledu zdravlja i ishrane (2003-2006) pokazuje da je upotreba DS veća za 7-14\% kod žena svih starosnih grupa [6], dok je naša studija pokazala da $15 \%$ više žena koristi DS. Muškarci i žene međusobno imaju različite percepcije o zdravstvenim navikama, kao i o navikama vezanim za ishranu i životni stil. Istraživanja vezana za ishranu i životne navike ukazuju da žene mnogo više vode računa o svom zdravstvenom stanju u odnosu na muškarce.

DS su najčešće koristili ispitanici starosne grupe od 38-48 godina i ispitanici stariji od 68 godina. Prethodno objavljene studije su pokazale da učestalost upotrebe DS raste sa starošću ispitanika, tako da osobe preko 71 godine starosti najviše konzumiraju DS $[4,12]$. Češća upotreba kod pacijenata starijih od 68 godina je očekivana i u vezi je sa većim brojem komorbiditeta kod osoba starije životne dobi. Visok procenat upotrebe DS kod ispitanika starosne grupe 38-48 godina je neočekivan, a razlozi za to mogu biti suplementacija ishrane zbog neadekvatnog unosa putem hrane, suplementacija u cilju prevencije bolesti i unapređenje zdravlja, koje može biti ugroženo zbog savremenog načina života.

Upotreba DS se povezuje sa zdravim načinom života (uzdržavanje od pušenja, niži indeks telesne mase, fizička aktivnost), zatim sa većim prihodima, višim nivoom zdravstvenog osiguranja i višim nivoom obrazovanja [6]. U našem istraživanju je pokazana razlika u upotrebi DS među ispitanicima različitog nivoa obrazovanja. Redovna i povremena upotreba DS je najčešća 
među ispitanicima sa visokim obrazovanjem. Najveći procenat ispitanika sa osnovnom školom ne koriste DS $(61,5 \%)$ u odnosu na ispitanike sa srednjom školom $(56,0 \%)$ i ispitanike sa višom školom i fakultetom (45,5\%). I prethodne studije su pokazale da je jedan od prediktora upotrebe DS viši nivo obrazovanja $[2,3,12]$.

Do sada objavljene studije pokazuju da je najraširenija upotreba multi-vitaminsko-mineralnih preparata $[3,5,6,11,12]$. Anketa o nacionalnom pregledu zdravlja i ishrane (2011-2014) je pokazala da Amerikanci najčešće koriste vitamin $\mathrm{D}$, a vitamin $\mathrm{K}$ najmanje, dok je od mineralnih preparata najčešće korišćen kalcijum, a najmanje gvožđe [4]. Studija sprovedena u Danskoj koja je obuhvatila skoro 10.000 ispitanika, starosti od 50-64 godine pokazale da su najčešće korišćeni suplementi multi-vitaminsko-mineralni preparati, antioksidansi i omega-3 masne kiseline. Vrsta korišćenih DS u našoj studiji se značajno razliku od rezultata prethodno objavljenih studija. Samo 4 ispitanika je prijavilo upotrebu multi-vitaminsko-mineralnih preparata. Najčešće korišćen vitamin je vitamin C, a najmanje vitamin D. Od DS na bazi pojedinih minerala najčešće je upotrebljavan magnezijum, dok su preparati gvožđa bili najmanje zastupljeni u suplementaciji (Slika 3).

Studije takođe pokazuju raširenu upotrebu omega-3 masnih kiselina i ribljeg ulja kako među starijom populacijom [12], tako i među studentima [7]. U našoj studiji samo 6 ispitanika je koristilo omega-3 masne kiseline. Omega-3 masne kiseline imaju brojne povoljne efekte na zdravlje čoveka: smanjuju oslobađanje prostanglandina i leukotriena koji su medijatori zapaljenja, smanjuju koncentraciju triglicerida, povećavaju nivo HDL holesterola i umanjuju rizik od srčanog i moždanog udara, preveniraju poremećaj srčanog ritma, smanjuju rizik od nastanka tromba [13]. Pored toga, ishrana na ovim prostorima ne sadrži dovoljne količine ovih nezasićenih masnih kiselina. I pored dokazanih povoljnih efekata na zdravlje ljudi, upotreba omega-3 masnih kiselina je niska među ispitivanom populacijom $(3,5 \%$ od ukupnog broja ispitanika). I učestalost upotrebe biljnih suplemenata je manja u odnosu učestalost pokazanu u drugim studijama. Anketa o nacionalnom pregledu zdravlja i ishrane (2003-2006) je pokazala da 14,0\% odraslih u Americi koriste DS sa najmanje jednim biljnim sastojkom [5], dok je u našoj studiji upotrebu biljnih preparata prijavilo $10,2 \%$ ispitanika.

Pokazana je značajno češća upotreba magnezijuma, zatim gvožđa, kalcijuma i vitamina D kod žena u odnosu na muškarce. Češća upotreba ovih preparata kod žena je opravdana. Žene češće mogu biti pogođene nedostatkom gvožđa usled menstrualnih krvarenja. Razlog češće upotrebe kalcijuma i vitamina $D$ kod žena je taj što se, starenjem i ulaskom u menopauzu, smanjuje koncentracija estrogena i dolazi do povećanog rizika od osteoporoze.

Prethodna istraživanja su pokazala da ispitanici najčešće koriste DS u cilju unapređenja zdravlja. Studenti farmacije u Americi su najčešće koristili DS u cilju prevencije bolesti, poboljšanja sportske sposobnosti, unapređenja imuniteta [7]. Anketa o nacionalnom pregledu zdravlja i ishrane (2007-2010) je pokazala da korisnici DS mnogo češće upotrebljavaju suplemente zbog unapređenja zdravlja nego u cilju suplementacije ishrane [6]. Neke studije su pokazale da su ispitanici najčešće motivisani da koriste DS zbog svoje osnovne bolesti i određenih zdravstvenih tegoba koje imaju (bolovi u zglobovima, osteoporoza, arthritis, grčevi u mišićima) naročito starija populacija $[8,9]$. Razlozi upotrebe DS koje su ispitanici u ovoj studiji navodili su: unapređenje imuniteta (36 ispitanika), unapređenje zdravlja (34 ispitanika), zatim prevencija bolesti (12 ispitanika), unapređenje ishrane (11 ispitanika). Za razliku od prethodnih studija, naša studija je pokazala da najmanji broj ispitanika (7 ispitanika) koristi DS zbog svoje osnovne bolesti. Sa druge strane, pojedine studije ukazuju da osobe sa jednom ili više dijagnoza ne postaju naglo korisnici DS, već da osobe koje već koriste pojedine suplemente mogu koristiti još neki suplement zbog bolesti koju imaju.

Najveći broj korisnika (73,8\%), DS kupuje u apotekama. Prema rezultatima našeg istraživanja ispitanici informacije o DS dobijaju u najvećem broju od farmaceuta $(26,3 \%)$ i lekara $(22,5 \%)$, Veliki broj žena $(73,0 \%)$ ima samo jedan izvor informacija, i to su lekari ili farmaceuti. Nešto manji procenat muškaraca $(60,0 \%)$ je navelo jedan izvor informacija. Najveći broj ispitanika muškog pola se o DS informiše putem interneta, zatim informacije dobija od farmaceuta, dok nijedan ispitanik nije naveo kao izvor informacija lekara. U Americi manje od $1 / 4$ suplemenata koje koriste odrasli ispitanici su bili preporučeni od strane lekara ili zdravstvenog radnika [6]. Istraživanje sprovedeno u Danskoj je pokazalo da ispitanici koji koriste i oni koji ne koriste DS svoje odluke o DS baziraju isključivo na osnovu svojih mišljenja. Pored toga, korisnici DS smatraju da lekari i dijetetičari znaju malo ili skoro ništa o ishrani i DS [9]. Nasuprot tome, najveći broj korisnika DS u našoj studiji je smatralo da farmaceuti daju dovoljno informacija o upotrebi DS (80,0 \%), a samo $20,0 \%$ je smatralo je da u apoteci ne dobijaju dovoljno informacija. S obzirom na raširenu upotrebu DS i na činjenicu da je ipak primarno mesto kupovine DS apoteka, veoma je važno da farmaceuti poseduju dovoljno znanja o DS. Prethodno izvedene studije su pokazale da farmaceuti koji rade u apotekama otvorenog tipa, nemaju dovoljno znanja o DS i da nisu zadovoljni sa kvalitetom informacija koje su im dostupne $[14,15]$. Zato je važno da farmaceuti imaju adekvatnu edukaciju o DS, tako da budu u mogućnosti da savetuju pacijente o pravilnoj upotrebi i doziranju DS, kao i da identifikuju kontraindikacije za upotrebu DS. Interakcije između DS i lekova mogu ugroziti zdravlje pacijenta i negativno uticati na tok bolesti. Veliki broj pacijenata, naročito starijeg doba koriste lekove i DS zajedno. Anketa o nacionalnom pregledu zdravlja i ishrane je pokazala da 34,3\% odraslih u SAD i 47,3\% pacijenata sa dijagnostifikovanom bolešću koristi zajedno lekova i DS [16]. Druga studija koja je obuhvatila stariju 
populaciju u SAD pokazala je da $52 \%$ osoba koristi DS uz terapiju [17]. Ove studije ukazuju da farmaceuti moraju da imaju izuzetno znanje o interakcijama između lekova i DS da bi mogli da ih identifikuju i da pruže najbolji izbor DS za svakog pacijenta.

Pored zdravstvenih radnika, korisnici dobijaju informacije o DS iz drugih izvora, kao što su internet, televizija, popularni časopisi, dnevna štampa. Reklame i mediji imaju veliki uticaj na upotrebu i izbor DS od strane potrošača. Značajan procenat korisnika u ovoj studiji, informacije o DS dobija putem interneta (16.3\%), televizije $(5,0 \%)$ i štampanih medija (3,0\%). Takođe, muškarci kao primarni izvor informacija navode internet. Korisnici su često zbunjeni zbog različitih informacija koje dobijaju iz različitih izvora. Stoga je zdravstveni značaj DS je jedno od važnih naučnih pitanja koje zahtevaju odgovornu komunikaciju putem medija. Jedan od načina da se to obezbediti jeste da mediji koriste eksperte i naučnike kao primarni izvor infromacija. Novinari i urednici u medijima konsultuju eksperte koji će pružiti prave informacije potrošačima o DS. Pored toga, odgovornost imaju i proizvođači i regulatorna tela da korisnici u svakom trenutku dobijaju prave informacije o delovanju DS.

Naše istraživanje je pokazalo vrlo pozitivan stav korisnika prema DS. Najveći broj ispitanika koji koriste DS $(93,7 \%)$ smatra da oni imaju povoljne efekte po zdravlje čoveka. Mali broj ispitanika (6,3 \%) je prilikom upotrebe DS imalo neke neželjene efekte. Prema istraživanju koje je rađeno u Australiji, oko $20 \%$ korisnika je navelo neke neželjene efekte. Druga studija je prijavila manji procenat pojave neželjenih efekata kod upotrebe DS - $2 \%$ kod populacije studenata farmacije [7]. Najveći broj ispitanika (65,0 \%) u ovoj studiji smatra da su dovoljno informisani o DS. Najveći deo ispitanika smatra da je važno pročitati deklaraciju (82,5 \%) i pridržava se uputstva za upotrebu (94,0\%). Ipak, najveći broj ispitanika smatra da su DS skupi. I druge studije govore u prilog tome. Nacionalni centar za zdravstvenu statistiku, u studiji koja je obuhvatila preko 11.000 ispitanika, pokazao je da svi indikatori ekonomskog statusa utiču na učestalost upotrebe DS, kao i na vrstu i broj DS koji se koriste [4].

\section{ZAKLJUČAK}

Ova studija je pokazala nižu zastupljenost i redovne i povremene upotrebe DS u ispitivanoj populaciji, u odnosu na rezultate koji su pokazani u prethodno izvedenim studijama u razvijenim zemljama. Pokazano je da je češća upotreba DS povezana sa ženskim polom, višim nivoom obrazovanja, kao i sa starijom dobi ispitanika. Pored toga, i vrsta korišćenih DS u našoj studiji se značajno razlikuje od DS koji se koriste u prethodno objavljenim studijama u Americi, Danskoj, Australiji. Za razliku od drugih zemalja, naši ispitanici uglavnom DS kupuju u apotekama i najviše informacija dobijaju od farmaceuta i lekara. Stoga je veoma važno da farma- ceuti imaju adekvatnu edukaciju o DS, da poseduju dovoljno znanja o DS i tako da budu u mogućnosti da savetuju pacijente o pravilnoj upotrebi i doziranju DS, da identifikuju kontraindikacije za upotrebu DS i interakcije između dijetetskih suplemenata i lekova. lako ispitanici smatraju da su dobro informisani o DS, na osnovu učestalosti i vrsti DS koji se koriste, potrebno je da zdravstveni radnici, u prvom redu farmaceuti, edukuju pacijente o delovanju i doziranju DS, kao i da učestvuju u izboru pravog DS za svakog korisnika.

\section{LITERATURA}

1. Pravilnik o zdravstvenoj ispravnosti dijetetskih proizvoda. Službeni glasnik RS br. 45/2010, 27/2011, 50/2012, 21/2015, 75/2015, 7/2017.

2. Dickinson A, Blatman J, El-Dash N, Franco JC. Consumer usage and reasons for using dietary supplements: report of a series of surveys. J Am Coll Nutr 2014;33(2):176-82.

3. Kofoed CL, Christensen J, Dragsted LO, Tjønneland A, Roswall N. Determinants of dietary supplement use-healthy individuals use dietary supplements. Br J Nutr 2015;113(12):1993-2000.

4. Cowan AE, Jun S, Gahche JJ, Tooze JA, Dwyer JT, EicherMiller HA, Bhadra A, Guenther PM, Potischman N, Dodd KW, Bailey RL. Dietary Supplement Use Differs by Socioeconomic and Health-Related Characteristics among U.S. Adults, NHANES 2011-2014. Nutrients 2018;10, 1114.

5. Bailey RL, Gahche JJ, Lentino CV, Dwyer JT, Engel JS, Thomas PR, Betz JM, Sempos CT, Picciano MF: Dietary supplement use in the United States, 2003-2006. J Nutr 2011;141(2):261-6.

6. Bailey RL, Gahche JJ, Miller PE, Thomas PR, Dwyer JT. Why US adults use dietary supplements. JAMA Intern Med 2013;173(5):355-61.

7. Axon DR, Vanova J, Edel C, Slack M. Dietary Supplement Use, Knowledge, and Perceptions Among Student Pharmacists. Am J Pharm Educ 2017;81(5):92.

8. Brownie S, Rolfe M. Supplement utilisation patterns of older Australians: results from a randomly selected national sample. Nutr Diet 2005;62:89-94.

9. Pajor EM, Oenema A,Eggers SM, de Vries H. Exploring beliefs about dietary supplement use: focus group discussions with Dutch adults. Public Health Nutr 2017;20(15):2694-05.

10. Kantor ED, Rehm CD, Du M, White E, Giovannucci EL. Trends in Dietary Supplement Use Among US Adults From 1999-2012. JAMA 2016;316(14):1464-74.

11. Dickinson A, MacKay D. Health habits and other characteristics of dietary supplement users: a review. Nutr J 2014;13:14.

12. O'Brien SK, Malacova E, Sherriff JL, Black LJ. The Prevalence and Predictors of Dietary Supplement Use in the Australian Population. Nutrients 2017;9, 1154.

13. Jain AP, Aggarwal KK, Zhang PY. Omega-3 fatty acids and cardiovascular disease. Eur Rev Med Pharmacol Sci 2015;19(3):441-45.

14. Nathan JP, Cicero LA, Koumis T, et al. Availability of and attitudes toward resources on alternative medicine products in the community pharmacy setting. J Am Pharm Assoc 2005;45(6):734-9. 
15. Zeolla MM, Cerulli J. Use of and familiarity with dietary supplement information references by practicing pharmacists. J Am Pharm Assoc 2008;48(3):401-4.

16. Farina EK, Austin KG, Lieberman HR. Concomitant dietary supplement and prescription medication use is prevalent among US adults with doctor-informed medical conditi- ons. J Acad Nutr Diet 2014;114(11):1784-90.

17. Qato DM, Alexander GC, Conti RM, et al. Use of prescription and over-the-counter medications and dietary supplements among older adults in the United States. JAMA 2008;300(24):2867-78.

\section{Upotreba, informisanost i stavovi o dijetetskim suplementima stanovnika Vukovara, Republika Hrvatska}

\author{
Ivana Baralić ${ }^{1,2}$, Brižita Đorđević3 \\ Senka Milinković ${ }^{4}$ \\ ${ }^{1}$ Kliničko bolnički centar Zvezdara, Dimitrija \\ Tucovića 161, 11000 Beograd, Srbija \\ 2Univerzitet Bijeljina, Farmaceutski fakultet, \\ Pavlovića put bb, 76300 Bijeljina, Republika \\ Srpska
}

${ }^{3}$ Katedra za bromatologiju, Farmaceutski fakultet, Univerzitet u Beogradu, Vojvode Stepe 450, 11000 Beograd, Srbija

${ }^{4}$ ZUA Zegin Farm - Ogranak Šid, 22400 Šid, Srbija

\begin{abstract}
Kratak sadržaj
Analiza upotrebe dijetetskih suplemenata (DS) je veoma važna s obzirom na rasprostranjenost njihove upotrebe, a može ukazati na potrebu i puteve racionalizacije upotrebe takvih proizvoda. Ciljovog istraživanja je bio da se proceni učestalost upotrebe, vrsta najčešće korišćenih dijetetskih suplemenata, razlog upotrebe, izvori informacija i preporuka za upotrebu dijetetskih suplementa, informisanost i stavovi korisnika o dijetetskim suplementima u gradu Vukovaru, Republika Hrvatska, kao i povezanost upotrebe sa godinama, polom i obrazovanjem. Deskriptivnim epidemiološkim ispitivanjem obuhvaćeno je 173 ispitanika, koji su bili korisnici/pacijenti apoteka "Teapharm (Vaše zdravlje)" u Vukovaru i koji su dobrovoljno pristupili popunjavanju anonimne ankete. U cilju prikupljanja podataka korišćen je originalni upitnik. Od ukupnog broja ispitanika, 9,8\% izjasnilo se da redovno koristi dijetetske suplemente, 37,0\% ispitanika da povremeno koristi, dok najveći broji ispitanika uopšte ne koristi dijetetske suplemente. Žene su znatno češće $(53,6 \%)$ u odnosnu na muškarce (38,2\%), koristile dijetetske suplemente. Redovna, kao i povremena upotreba DS je najčešća među ispitanicima sa visokim obrazovanjem. Kao razlog upotrebe, najveći broj ispitanika (36 ispitanika), navelo je unapređenje imuniteta. Najveći broj ispitanika $(73,8$ \%) dijetetske suplemente kupuje u apotekama, zatim u prodavnicama zdrave hrane $11,3 \%$, u supermarketu samo 10,0 \% ispitanika. Najveći broj ispitanika je informacije o dijetetskim suplementima dobio od farmaceuta i lekara. Ova studija je pokazala nižu zastupljenost i redovne i povremene upotrebe DS u ispitivanoj populaciji, u odnosu na rezultate koji su pokazani u prethodno izvedenim studijama u razvijenim zemljama. Pokazano je da češća upotreba DS povezana sa ženskim polom, višim nivoom obrazovanja, kao i sa starijom dobi ispitanika. Korisnici dijetetske suplemente uglavnom kupuju u apotekama i najviše informacija dobijaju od farmaceuta i lekara. Stoga je veoma važno da farmaceuti imaju adekvatnu edukaciju i tako da budu u mogućnosti da pravilno savetuju pacijente o upotrebi dijetetskih suplemenata.
\end{abstract}

Ključne riječi: dijetetski suplementi, zdravstveni radnici, učestalost upotrebe. 